\title{
SYNTHESIS AND CHARACTERIZATION OF NEW HETEROMETALLIC COMPLEXES CONTAINING TWO PYRAZOLIDE BRIDGES
}

\author{
Claudio Pettinari
}

Dip. Scienze chimiche, Università degli Studi di Camerino, Via S. Agostino 1, I - 62032 Camerino, Italy

\begin{abstract}
The platinum(II) derivative (DPE)Pt(pz) 2 (L) where DPE stands for 1,2bis(diphenylphosphino)ethane, and $\mathrm{pzH}$ for pyrazole, gives $1: 1$ adducts with $\mathrm{CdX}_{2}(\mathrm{X}=\mathrm{CI}, \mathrm{I})$, $\mathrm{HgX}_{2}(\mathrm{X}=\mathrm{I}, \mathrm{Br}), \mathrm{AuCl}$ and $\mathrm{PdCl}_{2}$ and $1: 2$ adducts with $\mathrm{HgX}_{2}(\mathrm{X}=\mathrm{CI}, \mathrm{Br})$. The compounds have been characterized by elemental analysis and spectroscopy (IR, ${ }^{1} \mathrm{H},{ }^{13} \mathrm{C},{ }^{31} \mathrm{P}$ NMR for the soluble compounds). The reactions of $\mathrm{L}$ with several $\mathrm{R}_{n} \mathrm{SnCl}_{4-n}, \mathrm{ZnX}_{2}$ and $\mathrm{CoX}_{2}(\mathrm{X}=\mathrm{CI}$ or $\mathrm{Br})$ have been investigated: in all cases cleavage of platinum-nitrogen bonds was observed and the likely polynuclear $\left[\mathrm{R}_{n} \mathrm{SnCl}_{4-n-2}(\mathrm{pz})_{2}\right]_{n},\left[\mathrm{Zn}(\mathrm{pz})_{2}\right]_{n}$ and $\left[\mathrm{Co}(\mathrm{pz})_{2}\right]_{n}$ are respectively obtained.
\end{abstract}

\section{Introduction}

We have recently reported on the synthesis, reactivity and spectroscopic characterization of complexes of main groups and transition elements with poly(azol-1-yl)alkanes ${ }^{l}$, a family of stable and flexible nitrogen-donor polidentate ligands, discovered by Trofimenko ${ }^{2}$, which have been shown to afford several type of complexes, depending on the nature of the acceptor and on the steric and electronic properties of the donor.

Several platinum bis(pyrazolide)complexes (Fig. 1), homologues of poly(azol-1-yl)alkanes, able to act as bidentate chelating ligands affording both 1:1 and 2:1 adducts, have been described in 1977 by Minghetti $e t a^{3}$. These molecules are of interest for their potential role in homogeneous catalysis $^{4}$ and for the unusual electronic and magnetic properties due to possible strong metal-metal interaction 5 .

It thus seemed of interest to extend our research to study of interaction between these molecules and several transition and main groups metal ions and we report here the initial results on the chelating ability of [(DPE) $\left.\operatorname{Pt}(\mathrm{pz})_{2}\right]$.

\section{Material and methods}

The samples for microanalysis were dried in vacuo to constant weight $\left(20^{\circ} \mathrm{C}, \mathrm{ca} 0.1\right.$ Torr). Elemental analyses (CHN) were carried out in the house with a Carlo Erba model 1106 instrument. IR spectra were recorded from 4000 to $100 \mathrm{~cm}^{-1}$ and from 4000 to $600 \mathrm{~cm}^{-1}$ with a Perkin-Elmer instrument System 2000 FT-IR and a 1600 Series FT-IR instrument, respectively. ${ }^{1} \mathrm{H}$ - ${ }^{31} \mathrm{P}$ - and ${ }^{13} \mathrm{C}$ NMR spectra were recorded on a VX-300 Varian spectrometer operating at room temperature (300 MHz for ${ }^{1} \mathrm{H}, 121.4 \mathrm{MHz}$ for ${ }^{31} \mathrm{P}$ and $75 \mathrm{MHz}$ for ${ }^{13} \mathrm{C}$ ). Melting points were taken on an IA 8100 Electrothermal instrument. The electric resistance of solutions was measured with a Crison CDTM 522 conductimeter at room temperature.

The ligand (DPE)Pt(pz) $(\mathrm{L})$ was prepared according to the literature method ${ }^{6}$. The other chemicals were analytical reagent grade. 


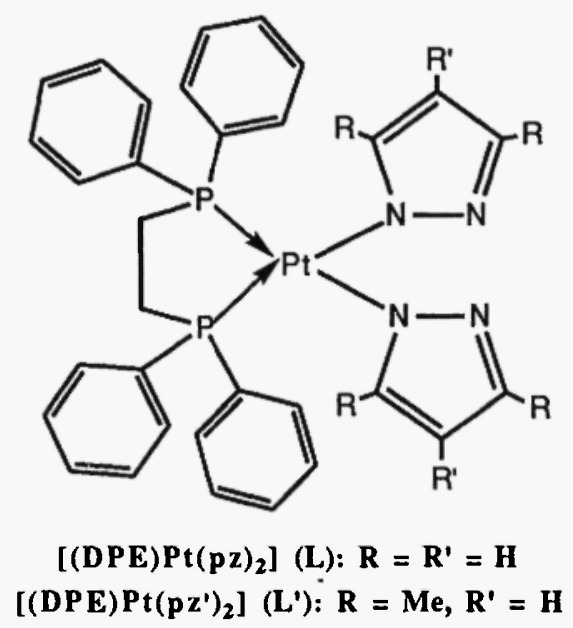

Fig. 1. Structure of the bis(pyrazolide)platinum(II) ligands.

\section{Synthesis of the adducts 1-8}

A diethyl ether solution $\left(10 \mathrm{~cm}^{3}\right)$ of mercury(II) bromide $(180 \mathrm{mg}, 0.5 \mathrm{mmol})$ was added dropwise to a stirred suspension $\left(20 \mathrm{~cm}^{3}\right)$ of the ligand (DPE)Pt(pz) 2 (L) $(364 \mathrm{mg}, 0.5 \mathrm{mmol})$ in the same solvent. A white crystalline precipitate separated out, which was filtered 2 days later and washed with diethyl ether to afford compound 3 ( $245 \mathrm{mg}, 0.45 \mathrm{mmol}$ ); it was purified by dissolving in methylene chloride $\left(10 \mathrm{~cm}^{3}\right)$ and precipitating with diethyl ether $\left(15 \mathrm{~cm}^{3}\right)$ to give the analytical sample $(218 \mathrm{mg}, 0.40 \mathrm{mmol})$. Compounds $1,2,4,5$ and 7 were prepared similarly, while compound 6 was obtained from a methanol solution. Compound 8 was obtained by adding a diethyl ether suspension $\left(20 \mathrm{~cm}^{3}\right)$ of the donor $\mathrm{L}(365 \mathrm{mg}, 0.5 \mathrm{mmol})$ to a stirred suspension of $\left(\mathrm{CH}_{3}\right)_{2} \mathrm{SAuCl}(147 \mathrm{mg}, 0.5 \mathrm{mmol})$ in the same solvent $\left(15 \mathrm{~cm}^{3}\right)$. The reaction mixture was stirred for two days and then evaporated to dryness. The residue was extracted with dichloromethane and the extract concentrated to $3 \mathrm{~cm}^{3}$; addition of diethyl ether $\left(10 \mathrm{~cm}^{3}\right)$ gave a white crystalline precipitate which was filtered and washed with hot methanol $\left(20 \mathrm{~cm}^{3}\right)(432 \mathrm{mg}, 0.45 \mathrm{mmol})$.

Reaction of (DPE)Pt(pz $)_{2}$ with $R_{n} \mathrm{SnX}_{4, n}, \mathrm{ZnX}_{2}$ and $\mathrm{CoX}_{2}(\mathrm{X}=\mathrm{Cl}$ or $\mathrm{Br})$

A diethyl ether solution $\left(10 \mathrm{~cm}^{3}\right)$ of $\mathrm{CH}_{3} \mathrm{SnCl}_{3}(120 \mathrm{mg}, 0.5 \mathrm{mmol})$ was added dropwise to a stirred suspension $\left(20 \mathrm{~cm}^{3}\right)$ of the ligand (DPE)Pt(pz) 2 (L) $(363 \mathrm{mg}, 0.5 \mathrm{mmol})$ in the same solvent. A white crystalline precipitate separated out. After 1 day the suspension was filtered and the precipitate washed with diethyl ether $\left(10 \mathrm{~cm}^{3}\right)$ and shown to be (DPE) $\mathrm{PtCl}_{2}$ by analytical and spectral data which are in accordance with those reported in literature? ${ }^{7}$. The solution was evaporated to dryness and the residue washed with dichloromethane to afford compound $\left[\left(\mathrm{CH}_{3}\right)(\mathrm{pz})_{2} \mathrm{SnCl}\right]_{n}(0.23 \mathrm{~mol}, 45 \%)$, m.p. $>250^{\circ} \mathrm{C}$; IR (nujol mull): $3110 \mathrm{w}, 571 \mathrm{~m}, 339 \mathrm{~m}, 320 \mathrm{~s}$, 249 m. Found: $\mathrm{C}, 27.9 ; \mathrm{H}, 3.1 ; \mathrm{N}, 18.6$; calcd for $\mathrm{C}_{7} \mathrm{H}_{9} \mathrm{ClN}_{4} \mathrm{Sn}$ : C, 27.7; H, 3.0, N, 18.5.; ${ }^{1} \mathrm{H}$ NMR (DMSO, $\delta$ ): $7.60 \mathrm{~s} \mathrm{br,} \mathrm{6.30s} \mathrm{br,} 1.0 \mathrm{br}$. 


\section{Results and Discussion}

The interaction between [(DPE)Pt(pz $)_{2}$ ] and several anhydrous cadmium and mercury(II) halide acceptors in diethyl ether and/or methanol afforded the corresponding adducts 1-4 (Table 1) according to the following general equation 1 :

$$
\left(\mathrm{MX}_{2}\right)+\left[(\mathrm{DPE}) \operatorname{Pt}(\mathrm{pz})_{2}\right] \longrightarrow(\mathrm{DPE}) \operatorname{Pt}(\mathrm{pz})_{2}\left(\mathrm{MX}_{2}\right) \quad I
$$

The $1: 1$ adduct [(DPE)Pt(pz $\left.)_{2}\right] \mathrm{HgCl}_{2}$ previously synthesized by Bandini et al ${ }^{8}$ was also obtained when the reaction was carried out in methanol whereas in diethyl ether with $\mathrm{HgCl}_{2}$ and $\mathrm{HgBr}_{2}$ the sparingly soluble 1:2 adducts 5 and $\mathbf{6}$ were respectively isolated: the obtainment of this type of compounds also when the reaction was carried out in a strong excess of the (DPE)Pt(pz $)_{2}$ donor can appear surprising but could be explainable with the strong and well-known tendency ${ }^{9}$ of mercury(II) derivatives to afford chlorine-bridged structures involving tetrahedrally coordinated $\mathrm{Hg}$ (II) species of the type shown in Fig. 2.

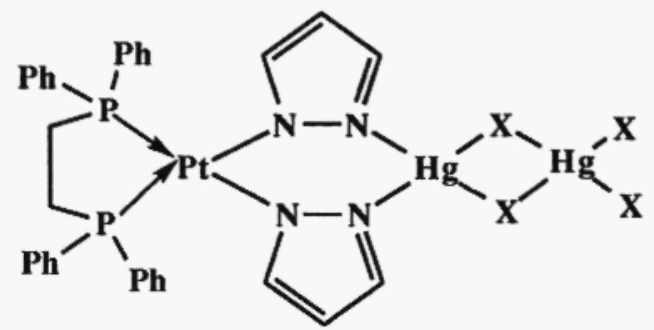

Fig. 2. Structure proposed for compounds 5 and 6.

No 1:2 adduct was synthesized when the reaction betwen [(DPE)Pt(pz $)_{2}$ ] and $\mathrm{HgI}_{2}$ was carried out in ether in a strong excess of acceptor. Attempts to obtain 1:2 adducts by reaction of 3 and 4 with $\mathrm{HgBr}_{2}$ and $\mathrm{HgI}_{2}$ respectively, were also unsuccessful.

The complexes [(DPE)Pt $\left.(\mathrm{pz})_{2}(\mathrm{PdCl})\right], 7$ and $\left[(\mathrm{DPE}) \operatorname{Pt}(\mathrm{pz})_{2}(\mathrm{AuCl})\right] \mathbf{8}$, were instead obtained by displacement by (DPE)Pt(pz $)_{2}$ of a labile or volatile ligand such as acetonitrile or dimethylsulphoxide from $\left(\mathrm{CH}_{3} \mathrm{CN}\right)_{2} \mathrm{PdCl}_{2}$ and $\left(\mathrm{CH}_{3}\right)_{2} \mathrm{SAuCl}$ respectively.

The reactions of (DPE)Pt(pz $)_{2}$ with several tin(IV) and organotin(IV) derivatives, namely $\left(\mathrm{CH}_{3}\right)_{2} \mathrm{SnCl}_{2}, \mathrm{Ph}_{2} \mathrm{SnCl}_{2}, \mathrm{CH}_{3} \mathrm{SnCl}_{3}$ and $\mathrm{SnCl}_{4}$ were carried out under a variety of conditions (in diethyl ether and under $\mathrm{N}_{2}$ stream, at room temperature or in refluxing ethanol, petroleum ether, $\mathrm{CH}_{2} \mathrm{Cl}_{2}$ or acetonitrile) but in any case DPEPtCl 2 was obtained: this implies a cleavage of the Pt-N bond and scrambling of the ligands, in accordance with eqn. 2 :

$$
\mathrm{R}_{\mathrm{n}} \mathrm{SnX}_{4-\mathrm{n}}+\left[(\mathrm{DPE}) \mathrm{Pt}(\mathrm{pz})_{2}\right] \longrightarrow\left[(\mathrm{DPE}) \mathrm{PtX}_{2}\right]+\left[\mathrm{R}_{\mathrm{n}}(\mathrm{pz})_{2} \mathrm{SnX}_{4-\mathrm{n}-2}\right] 2
$$

For example when the reaction between (DPE)Pt(pz) $)_{2}$ and $\mathrm{CH}_{3} \mathrm{SnCl}_{3}$ in diethyl ether was carried out, the formation of a precipitate by empirical composition $\mathrm{C}_{7} \mathrm{H}_{9} \mathrm{ClN} 4 \mathrm{Sn}$, has been observed. Poor solubility in most of the usual solvents prevented its full characterization. It's also impossible to record ${ }^{119} \mathrm{Sn}$ Mössbauer spectrum because of the extreme instability of the precipitate towards moisture. We tentatively postulate a polynuclear structure of the type $\left[\left(\mathrm{CH}_{3}\right)(\mathrm{pz})_{2} \mathrm{SnCl}\right]_{n}$ with bridging azolato groups between two tin(IV) atoms on the basis of previous reports on imidazolate and pyrazolate derivatives of trialkyltin(IV) acceptors ${ }^{10}$. 


\section{Table 1}

Physical, Analytical and conductivity data of derivatives 1-8

\begin{tabular}{|c|c|c|c|c|c|c|c|c|c|}
\hline $\begin{array}{l}\text { Compound } \\
\text { and formula } a\end{array}$ & & $\begin{array}{r}\text { ield } \\
\%\end{array}$ & $\begin{array}{l}\text { M.p. E } \\
\left({ }^{\circ} \mathrm{C}\right)\end{array}$ & $\begin{array}{c}\text { El. Analy } \\
\text { C }\end{array}$ & $\begin{array}{c}\text { es (\%); } \\
H\end{array}$ & $\begin{array}{l}\text { Found(Calc.) } \\
\qquad N\end{array}$ & $\begin{array}{l}\text { Conduc } \\
\text { solv. }\end{array}$ & $\begin{array}{l}\text { tivities } \\
\text { conc. }\end{array}$ & $\Lambda$ \\
\hline $\begin{array}{l}(\mathrm{DPE}) \mathrm{Pt}(\mathrm{pz})_{2} \mathrm{CdCl}_{2} \\
\mathrm{C}_{32} \mathrm{H}_{30} \mathrm{CdCl}_{2} \mathrm{~N}_{4} \mathrm{P}_{2} \mathrm{Pt} \\
(\mathrm{DPE}) \mathrm{Pt}(\mathrm{pz})_{2} \mathrm{CdI}_{2} \\
\mathrm{C}_{32} \mathrm{H}_{30} \mathrm{CdI}_{2} \mathrm{~N}_{4} \mathrm{P}_{2} \mathrm{Pt} \\
(\mathrm{DPE}) \mathrm{Pt}(\mathrm{pz})_{2} \mathrm{HgBr}_{2} \\
\mathrm{C}_{32} \mathrm{H}_{30} \mathrm{Br}_{2} \mathrm{HgN}_{4} \mathrm{P}_{2} \mathrm{Pt} \\
(\mathrm{DPE}) \mathrm{Pt}_{(\mathrm{pz})_{2} \mathrm{HgI}_{2}} \\
\mathrm{C}_{32} \mathrm{H}_{30} \mathrm{HgI}_{2} \mathrm{~N}_{4} \mathrm{P}_{2} \mathrm{Pt} \\
{\left[(\mathrm{DPE}) \mathrm{Pt}(\mathrm{pz})_{2}\left(\mathrm{HgBr}_{2}\right)_{2}\right]} \\
\mathrm{C}_{32} \mathrm{H}_{30} \mathrm{Br}_{4} \mathrm{Hg}_{2} \mathrm{~N}_{4} \mathrm{P}_{2} \mathrm{Pt} \\
{\left[(\mathrm{DPE}) \mathrm{Pt}_{2}\left(\mathrm{pz}_{2}\left(\mathrm{HgCl}_{2}\right)_{2}\right]\right.} \\
\mathrm{C}_{32} \mathrm{H}_{30} \mathrm{Cl}_{4} \mathrm{Hg}_{2} \mathrm{~N}_{4} \mathrm{P}_{2} \mathrm{Pt} \\
(\mathrm{DPE}) \mathrm{Pt}(\mathrm{pz})_{2} \mathrm{PdCl} \\
\mathrm{C}_{32} \mathrm{H}_{30} \mathrm{Cl}_{2} \mathrm{~N}_{4} \mathrm{P}_{2} \mathrm{PdPt} \\
(\mathrm{DPE}) \mathrm{Pt}\left(\mathrm{pz}_{2} \mathrm{AuCl}_{2} \mathrm{AuCl}\right. \\
\mathrm{C}_{32} \mathrm{H}_{30} \mathrm{AuClN}_{4} \mathrm{P}_{2} \mathrm{Pt}\end{array}$ & $\begin{array}{l}\text { (4) } \\
\text { (5) }\end{array}$ & 92 & $269-70$ & $\begin{array}{c}42.0 \\
(42.2) \\
35.2 \\
(35.1) \\
35.3 \\
(35.3) \\
32.3 \\
(32.5) \\
26.6 \\
(26.5) \\
30.0 \\
(30.3) \\
42.2 \\
(42.5) \\
40.2 \\
(40.0)\end{array}$ & $\begin{array}{c}3.2 \\
(3.3) \\
3.1 \\
(2.8) \\
2.8 \\
(2.8) \\
2.5 \\
(2.6) \\
2.1 \\
(2.1) \\
2.4 \\
(2.4) \\
3.5 \\
(3.3) \\
3.2 \\
(3.2)\end{array}$ & $\begin{array}{c}6.3 \\
(6.2) \\
4.9 \\
(5.1) \\
5.3 \\
(5.2) \\
4.4 \\
(4.7) \\
3.5 \\
(3.9) \\
4.3 \\
(4.4) \\
5.9 \\
(6.2) \\
5.4 \\
(5.8)\end{array}$ & $\begin{array}{l}\mathrm{CH}_{2} \mathrm{Cl}_{2} \\
\text { insoluble }\end{array}$ & 1.2 & 0.6 \\
\hline
\end{tabular}

${ }^{a} \mathrm{DPE}=1,2$-bis(diphenylphosphino)ethane, $\mathrm{pzH}=$ pyrazole.

${ }^{b}$ At room temperature and at the molar concentration $x 10^{-3}$.

Scrambling of the ligand occurred also when (DPE)Pt(pz $)_{2}$ reacts in ethanol and/or diethyl ether with $\mathrm{ZnCl}_{2}, \mathrm{Znl}_{2}$ and $\mathrm{CoCl}_{2}$, the well-known polymeric $\left[\mathrm{Zn}(\mathrm{pz})_{2}\right]_{n}$ and $\left[\mathrm{Co}(\mathrm{pz})_{2}\right]_{n}{ }^{11}$ respectively being formed.

The different behaviour of (DPE)Pt(pz $)_{2}$ with respect to (DPE)Pt(pz') ${ }_{2}$ previously investigated by Bandini $e t a l^{8}$ is likely due to presence in the latter of electron-releasing groups as the methyl, which makes $\mathrm{L}^{\prime}$ better donor than $\mathrm{L}$ and shields $\mathrm{Pt}(\mathrm{II})$ atom from chloride attack.

All the compounds 1-8 were identified through analytical data (Table 1) infrared (Table 2) and when possible also with magnetic resonance spectra (Tables 3,4 and 5 for ${ }^{1} \mathrm{H},{ }^{13} \mathrm{C}$ and ${ }^{31} \mathrm{P}$ NMR respectively). They are colourless (with exception of 7, which is pale-yellow), air stable, sparingly soluble in chlorinated solvents (with exception of 5 and 6) and in DMSO whereas they are generally insoluble in alcohol, acetone, and hydrocarbons. The molar conductivities in dichloromethane showed the complexes $1-4,7$ and 8 to be non-electrolytes, ruling out ionic formulae such as $\left.[D P E) \operatorname{Pt}(\mu-\mathrm{pz})_{2} \mathrm{M}(\mu-\mathrm{pz})_{2} \mathrm{Pt}(\mathrm{DPE})\right]^{2+}\left[\mathrm{MX}_{4}\right]^{2-}$ or ionic dissociation such as 3.

$$
\left[(\mathrm{DPE}) \operatorname{Pt}(\mathrm{pz})_{2} \mathrm{MX}_{2}\right] \stackrel{\mathrm{S}}{\longrightarrow}\left[(\mathrm{DPE}) \operatorname{Pt}(\mathrm{pz})_{2} \mathrm{M}(\mathrm{X})\right]^{+}+[\mathrm{X}]^{-} \quad 3
$$

The infrared spectra (Table 2) are in agreement with the formulae given. In all the compounds the bands typical of the azolato ligand are easily detected: weak and medium vibrations at $c a 3100 \mathrm{~cm}^{-1}$ due to $\mathrm{C}-\mathrm{H}$ stretching of the heterocyclic ring, and other more intense ones between 1600 and $1500 \mathrm{~cm}^{-1}$ typical of ring breathing ${ }^{12}$. No significative change was observed 
upon complexation, because we noted that in the $4000-600 \mathrm{~cm}^{-1}$ region the IR spectra of the adducts 1-8 resemble strictly that of the (DPE)Pt(pz)2.

Table 2

Selected IR data $\left(\mathrm{cm}^{-1}\right)^{a}$

\begin{tabular}{|c|c|c|c|c|c|c|}
\hline Compound & No. & $>3000$ & \multicolumn{2}{|c|}{$1600-1500$} & $<500$ & other data \\
\hline$(\mathrm{DPE}) \mathrm{Pt}(\mathrm{pz})_{2}$ & & $3118 w 3070 w$ & $1585 w$ & $1570 w$ & $540 \mathrm{~m}, 490 \mathrm{~m}, 475 \mathrm{w}$ & \\
\hline$(\mathrm{DPE}) \mathrm{Pt}(\mathrm{pz})_{2} \mathrm{CdCl}_{2}$ & (1) & $\begin{array}{l}3040 w \\
3140 w 3070 w\end{array}$ & $1590 w$ & & $\begin{array}{l}360 \mathrm{~m}, 270 \mathrm{w} \\
545 \mathrm{~m}, 495 \mathrm{~m}, 480 \mathrm{w}\end{array}$ & $2(\mathrm{Cd}-\mathrm{Cl}): 280 \mathrm{~m}$ \\
\hline$(\mathrm{DPE}) \mathrm{Pt}(\mathrm{pz})_{2} \mathrm{CdI}$ & (2) & $\begin{array}{l}3040 w \\
3110 w 3040 \text { sh }\end{array}$ & $1585 w$ & & $\begin{array}{l}450 w, 405 w \\
540 m, 490 w, 480 w\end{array}$ & \\
\hline $\begin{array}{l}(\mathrm{DPE}) \mathrm{Pt}(\mathrm{pz})_{2} \mathrm{HgBr}_{2} \\
(\mathrm{DPE}) \mathrm{Pt}(\mathrm{pz})_{2} \mathrm{HgI}_{2}\end{array}$ & (3) & $\begin{array}{l}3105 \mathrm{vw} 3060 \mathrm{w} \\
3110 \mathrm{w} 3070 \mathrm{w}\end{array}$ & $\begin{array}{l}1590 w \\
1590 w\end{array}$ & $1575 w$ & $\begin{array}{l}540 \mathrm{~s}, 490 \mathrm{~m}, 480 \mathrm{~m} \\
450 \mathrm{w}, 400 \mathrm{vw} \\
540 \mathrm{~m}, 490 \mathrm{~m}, 480 \mathrm{~m}\end{array}$ & \\
\hline $\begin{array}{l}{\left[(\mathrm{DPE}) \operatorname{Pt}(\mathrm{pz})_{2}\left(\mathrm{HgBr}_{2}\right)_{2}\right]} \\
{\left[(\mathrm{DPE}) \operatorname{Pt}(\mathrm{pz})_{2}\left(\mathrm{HgCl}_{2}\right)_{2}\right]}\end{array}$ & $\begin{array}{l}\text { (5) } \\
\text { (6) }\end{array}$ & $\begin{array}{l}3100 w \\
3108 w 3060 w\end{array}$ & $\begin{array}{l}1589 w \\
1590 w\end{array}$ & $\begin{array}{l}1570 w \\
1576 w\end{array}$ & $\begin{array}{l}460 \mathrm{w} \text { br } \\
535 \mathrm{~s}, 495 \mathrm{~s}, 480 \mathrm{~m} \\
540 \mathrm{~s}, 493 \mathrm{~m}, 485 \mathrm{~m}\end{array}$ & $\langle(\mathrm{Hg}-\mathrm{Cl}): 305 \mathrm{~m}$ \\
\hline $\begin{array}{l}(\mathrm{DPE}) \mathrm{Pt}(\mathrm{pz})_{2} \mathrm{PdCl}_{2} \\
(\mathrm{DPE}) \mathrm{Pt}(\mathrm{pz})_{2} \mathrm{AuCl}\end{array}$ & (7) & $\begin{array}{l}\text { 3040sh } \\
\text { 3140w, 3060w }\end{array}$ & $1585 w$ & $1570 w$ & $\begin{array}{l}441 w, 425 w \\
530 \mathrm{~m}, 488 \mathrm{~m} \text { br } \\
483 \mathrm{w}, 409 \mathrm{w} \\
538 \mathrm{~s}, 490 \mathrm{~m}, 480 \mathrm{w} \\
450 \mathrm{w}, 361 \mathrm{~m}\end{array}$ & 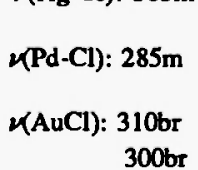 \\
\hline
\end{tabular}

$a_{\text {Nujol mull }}$

In the low-frequency region of compounds 1 and 6-8 bands due to metal-chloride stretching frequencies are also observed, whereas we find no evidence of $\mathrm{M}-\mathrm{N}$ stretching vibrations because they are likely hidden under some $\operatorname{DPEPt}(\mathrm{pz})_{2}$ absorptions.

The ${ }^{1} \mathrm{H}$ and ${ }^{13} \mathrm{C}$ NMR spectra (Tables 3 and 4), recorded for the sufficiently soluble derivatives, showed always bands due to bidentate P-donor ligand and two pyrazolato moieties, suggesting that the organic ligands have not undergone any structural change or rearrangement upon coordination.

All the signals assignable to proton of pyrazolate ring are generally shifted downfield upon complexation, whereas no conclusion could to be reached on the bis(diphenylphosphino)ethane protons because of the braodening of the absorption.

The ${ }^{13} \mathrm{C}$ NMR data of compounds 5-8 were not reported: in fact the expected signals are not detected because the poor solubility of compounds ( $c a 1.5 \times 10^{5}$ cycles acquired). In the spectra of derivatives 1-4 the complex patterns and/or the broadening of carbon signals is explainable with the non-equivalence of the phenyl rings due to restricted rotations of the phenyls around the $\mathrm{P}-\mathrm{C}$ bonds and with the poor solubility also.

The ${ }^{31} \mathrm{P}$ NMR spectra of complexes 1-4 and 7 show a single resonance in the region 32-35 ppm (external reference $85 \% \mathrm{H}_{3} \mathrm{PO}_{4}$ ) generally flanked by ${ }^{195} \mathrm{Pt}$ satellites with ${ }^{1} J_{\mathrm{Pt} \text {-P }}$ of $\mathrm{ca} 3.1$ $\mathrm{kHz}$. The two phosphorus nuclei are therefore magnetically equivalent also in these adducts, where the signals appear to be slightly deshielded with respect to that of the free donor.

In the ${ }^{31} \mathrm{P}$ spectrum of compound 8 two sharp resonances are observed, different from that of the starting $\mathrm{L}$ donor and indicative of magnetical non-equivalence of the two phosphorus atoms. Gold(I) compounds ${ }^{13}$ generally prefer bi-coordination and also in this compound likely only one pyrazolato group is coordinated to gold(I) atom, as proposed in Fig. 3. 
Table 3<smiles></smiles>

Fig. 3. Structure proposed for compound 8.

\section{${ }^{1}$ H NMR data $a$ for derivatives $1-8$}

\begin{tabular}{|c|c|c|c|c|c|c|c|}
\hline Compound & No & Solvent & $\mathbf{C H}_{2}$ & 3.CH & 4-CH & 5-CH & Aromatles \\
\hline$(\mathrm{DPE}) \mathrm{Pt}(\mathrm{pz})_{2}$ & & $\begin{array}{l}\mathrm{CD}_{2} \mathrm{Cl}_{2} \\
\mathrm{CDCl}_{3}\end{array}$ & $\begin{array}{l}2.2-2.4 \mathrm{~m} \text { br } \\
2.2-2.5 \mathrm{~m} \text { br }\end{array}$ & $\begin{array}{l}6.7 d \\
6.8 d\end{array}$ & $\begin{array}{l}5.9 \mathrm{pt} \\
5.9 \mathrm{pt}\end{array}$ & $\begin{array}{l}7.3 \mathrm{~d} \\
7.3 \mathrm{~d}\end{array}$ & $\begin{array}{l}7.4-7.6 \mathrm{~m}, 7.7-7.9 \mathrm{~m} \\
7.4-7.6 \mathrm{~m}, 7.7-7.9 \mathrm{~m}\end{array}$ \\
\hline$(\mathrm{DPE}) \mathrm{Pt}(\mathrm{pz})_{2} \mathrm{CdCl}$ & (1) & $\mathrm{CD}_{2} \mathrm{Cl}_{2}$ & $2.2-2.8 \mathrm{br}$ & $6.9 \mathrm{~d}$ & $6.0 \mathrm{pt}$ & & $7.4-7.9 \mathrm{~m}$ br \\
\hline \multirow[t]{3}{*}{$(\mathrm{DPE}) \mathrm{Pt}(\mathrm{pz})_{2} \mathrm{CdI} \mathrm{I}_{2}$} & (2) & $\mathrm{CD}_{2} \mathrm{Cl}_{2}$ & $2.0-3.0 \mathrm{br}$ & $7.0 \mathrm{br}$ & $6.0 \mathrm{br}$ & $b$ & $7.3-8.0 \mathrm{br}$ \\
\hline & & $\mathrm{CDCl}_{3}$ & $2.1-2.9 \mathrm{br}$ & $7.0 \mathrm{~d}$ & $6.0 \mathrm{pt}$ & $b$ & $7.3-7.7 \mathrm{~m}$ br, $7.8-8.0 \mathrm{~m} \mathrm{~b}$ \\
\hline & & $\begin{array}{l}\mathrm{C}_{5} \mathrm{D}_{5} \mathrm{~N} \\
\mathrm{C}_{6} \mathrm{D}_{4} \mathrm{NO}_{2}\end{array}$ & $\begin{array}{l}2.5-3.0 \mathrm{br} \\
2.5-3.0 \mathrm{br}\end{array}$ & $\begin{array}{l}7.1 \mathrm{br} \\
7.3 \mathrm{~d}\end{array}$ & $\begin{array}{l}6.0 \mathrm{br} \\
6.0 \mathrm{pt}\end{array}$ & $\begin{array}{l}b \\
7.8 d\end{array}$ & $\begin{array}{l}7.1-8.2 \mathrm{br} \\
7.5 \mathrm{~m}, 7.7 \mathrm{~m}, 8.1 \mathrm{~m}\end{array}$ \\
\hline$(\mathrm{DPE}) \mathrm{Pt}(\mathrm{pz})_{2} \mathrm{HgBr}_{2}$ & (3) & $\mathrm{CDCl}_{3}$ & $2.2-2.6 \mathrm{br}$ & $6.9 \mathrm{~d}$ & $5.9 \mathrm{pt}$ & $\boldsymbol{b}$ & $7.4-8.0 \mathrm{br}$ \\
\hline$(\mathrm{DPE}) \mathrm{Pt}(\mathrm{pz})_{2} \mathrm{HgI}_{2}$ & (4) & $\mathrm{CDCl}_{3}$ & $2.4-2.7 \mathrm{br}$ & $7.0 \mathrm{~d}$ & $6.0 \mathrm{pt}$ & $\boldsymbol{b}$ & $7.3-7.9 \mathrm{~m}$ br \\
\hline (DPE)Pt(pz) ${ }_{2} \mathrm{PdCl}_{2}$ & (7) & $\mathrm{CDCl}_{3}$ & $2.0-2.9 \mathrm{br}$ & $7.0 \mathrm{br}$ & $6.0 \mathrm{br}$ & $\boldsymbol{b}$ & $7.2-8.0 \mathrm{br}$ \\
\hline$(\mathrm{DPE}) \mathrm{Pt}(\mathrm{pz})_{2} \mathrm{AuCl}$ & (8) & $\mathrm{CDCl}_{3}$ & $2.2-2.9 \mathrm{br}$ & $7.0 \mathrm{br}$ & $6.0 \mathrm{br}$ & $\boldsymbol{b}$ & $7.1-8.0 \mathrm{br}$ \\
\hline
\end{tabular}

$a \quad \delta$ in ppm from internal TMS, $\mathrm{m}=$ multiplet, $\mathrm{d}=$ doublet, $\mathrm{pt}=$ pseudotriplet, $\mathrm{br}=$ broad.

$b$ The doublet due to $5-\mathrm{CH}$ could not be assigned because is hidden under the aromatic signals.

\section{Table 4}

${ }^{13} \mathrm{C}$ NMR data $a$ of derivatives $1-4$

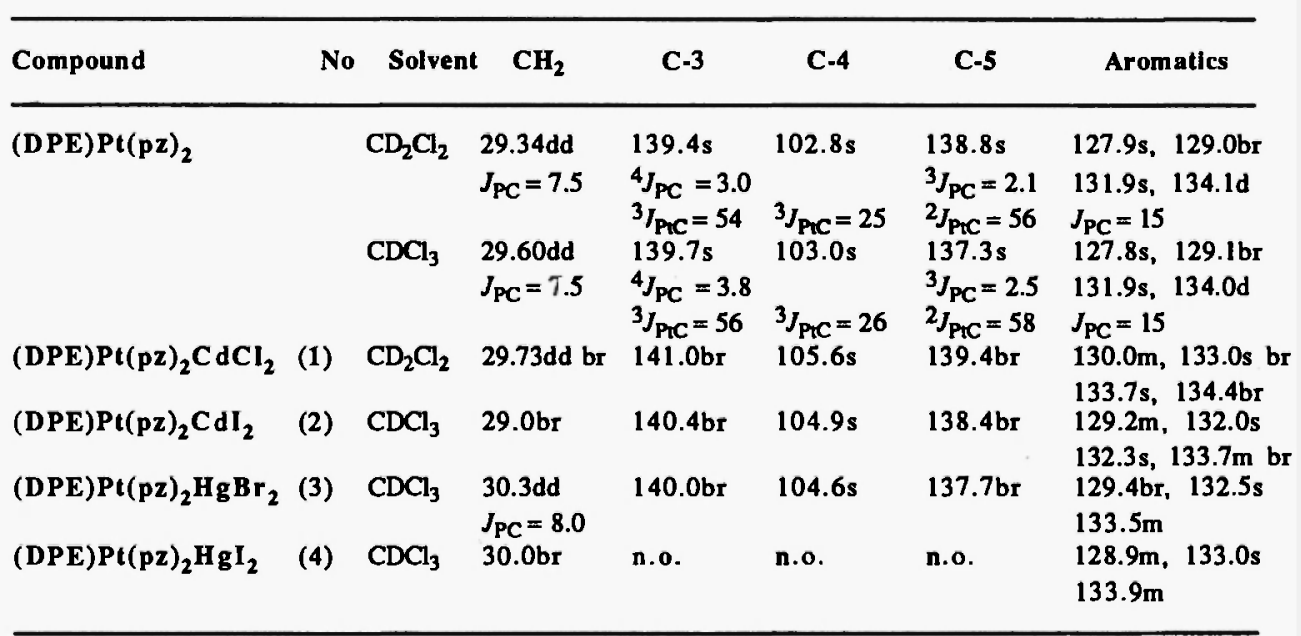

$a \delta$ in ppm from internal TMS, $\mathrm{m}=$ multiplet, $\mathrm{d}=$ doublet, $\mathrm{t}=$ triplet, $\mathrm{br}=$ broad; $\mathrm{J}$ in $\mathrm{Hz}$. 
Table 5

31P NMR data

\begin{tabular}{|c|c|c|c|c|}
\hline Compound & No. & Solvent & ${ }^{31} \mathbf{P} \delta$ & ${ }^{1} \mathrm{~J}(\mathrm{Pt}-\mathrm{P})$ \\
\hline $\begin{array}{l}(\mathrm{DPE}) \mathrm{PtCl}_{2} \\
(\mathrm{DPE}) \mathrm{Pt}(\mathrm{pz})_{2} \\
(\mathrm{DPE}) \mathrm{Pt}(\mathrm{pz})_{2} \mathrm{CdCl}_{2} \\
(\mathrm{DPE}) \mathrm{Pt}(\mathrm{pz})_{2} \mathrm{CdI}_{2} \\
(\mathrm{DPE}) \mathrm{Pt}(\mathrm{pz})_{2} \mathrm{HgBr}_{2} \\
(\mathrm{DPE}) \mathrm{Pt}(\mathrm{pz})_{2} \mathrm{HgI}_{2} \\
(\mathrm{DPE}) \mathrm{Pt}(\mathrm{pz})_{2} \mathrm{PdCl}_{2} \\
(\mathrm{DPE}) \mathrm{Pt}(\mathrm{pz})_{2} \mathrm{AuCl}\end{array}$ & $\begin{array}{l}(1) \\
(2) \\
(3) \\
(4) \\
(7) \\
(8)\end{array}$ & $\begin{array}{l}\mathrm{CDCl}_{3} \\
\mathrm{CDCl}_{3} \\
\mathrm{CD}_{2} \mathrm{Cl}_{2} \\
\mathrm{CD}_{2} \mathrm{Cl}_{2} \\
\mathrm{CDCl}_{3} \\
\mathrm{CDCl}_{3} \\
\mathrm{CDCl}_{3} \\
\mathrm{CDCl}_{3}\end{array}$ & $\begin{array}{l}41.6 \\
33.4 \\
35.8 \\
34.3 \\
35.0 \\
33.9 \\
37.0 \mathrm{br} \\
35.2 \\
38.6\end{array}$ & $\begin{array}{l}3636 \\
3123 \\
3160 \\
3131 \\
3161 \\
3120 \\
\text { n.o. } \\
\text { n.o. } \\
\text { n.o. }\end{array}$ \\
\hline
\end{tabular}

\section{Acknowledgements}

We would like to thank the Consiglio Nazionale delle Ricerche (CNR, Roma) and Ministero dell'Università e della Ricerca Scientifica e Tecnologica (M.U.R.S.T.) for financial support.

\section{References}

1. (a) F. Bonati, A. Cingolani, G. Gioia Lobbia, D. Leonesi, A. Lorenzotti and C. Pettinari, Gazz. Chim. Ital., 1990, 120, 341; (b) C. Pettinari, C. Santini, D. Leonesi, P. Cecchi, Polyhedron, 1994, 13, 1553; (c) C. Pettinari, A. Lorenzotti, A. Cingolani, D. Leonesi, M. Marra and F. Marchetti, Gazz. Chim. Ital, 1993, 123, 481.

2. S. Trofimenko, J. Am. Chem. Soc., 1970, 92, 5118.

3. G. Minghetti, G. Banditeli and F. Bonati, Chem. Ind. (London) 1977, 123.

4. (a) B. C. Hui and G. L. Rempel, Chem. Commun., 1970, 1195; (b) W. R. Cullen, T.-J. Kim, N. F. Han and J. Trotter, Inorg. Chem., 1987, 26, 514.

5. M. Inoue and M. Kubo, Coord. Chem. Rev., 1976, $21,1$.

6. (a) G. Banditelli, A. L. Bandini, F. Bonati and G. Minghetti, Inorg. Chim.Acta, 1982, 60, 93; (b) G. Minghetti, G. Banditelli and F. Bonati, J. Chem. Soc. Dalton Trans., 1979, 1851.

7. D. H. Farrar and G. Ferguson, J. Cryst. Spectrosc. Res., 1982, 12, 465 and references therein.

8. A. L. Bandini, G. Banditelli, G. Minghetti and F. Bonati, Can. J. Chem., 1979, 57, 3237.

9. W. Levason and C. A. McAuliffe, "The coordination Chemistry of Mercury" in The Chemistry of Mercury, C. A. McAuliffe ed., McMillan Press, London (1977).

10. J. G. A. Luijten and G. J. M. Van der Kerk, Rec. Trav. Chim., 1963, 82, 1181; J. G. A. Luijten, M. J. Janssen and G. J. M. Van der Kerk, Rec. Trav. Chim., 1962, 81, 202; R. Gassend, J. C. Maire, J. C. Pommier, J. Organomet. Chem., 1977, 132, 69.

11. J. G. Vos and W. L. Groeneveld, Inorg. Chim. Acta, 1977, 24, 123.

12. K. Nakamoto, in Infrared and Raman Spectra of Inorganic and Coordination Compounds, 4th edn, Wiley Interscience, New York (1986).

13. F. A. Cotton and G. Wilkinson, Advanced Inorganic Chemistry, 4th edn, Wiley Interscience, New York (1980), p. 975.

Received: January 3, 1995 - Accepted: January 25, 1995 - Received in camera-ready format: February 12, 1995 
